\title{
Perceptions and attitudes regarding organic waste: Feasibility of establishing an urban composting program in Chiapas, Mexico
}

Jorge Camacho Barboza, ${ }^{a}$ University of Padova, Department of Environmental Agriculture

Helda Morales, ${ }^{\mathrm{b}}$ El Colegio de la Frontera Sur, Department of Agroecology

Ricardo Alvarado Barrantes, ${ }^{\mathrm{c}}$ University of Costa Rica, Departament of Statistics

Antonio Saldivar Moreno, ${ }^{\mathrm{d}}$ El Colegio de la Frontera Sur, Department of Society, Culture, and Health

Esperanza Huerta Lwanga, ${ }^{\mathrm{e}}$ El Colegio de la Frontera Sur, Department of Agroecology

Submitted 6 July 2010 / Accepted 26 April 2011/ Published online 9 May 2011 / Revised 12 May 2011

Citation: Camacho Barboza, J., Morales, H., Alvarado Barrantes, R., Saldivar Moreno, A., \& Huerta Lwanga, E. (2011). Perceptions and attitudes regarding organic waste: Feasibility of establishing an urban composting program in Chiapas, Mexico. Journal of Agriculture, Food Systems, and Community Development, 1(3), 115-131. http://dx.doi.org/10.5304/jafscd.2010.013.006

Copyright (C) 2011 by New Leaf Associates, Inc.

\begin{abstract}
The poor management of household and municipal waste is a threat to the sustainability of urban communities throughout the world, and also

\footnotetext{
${ }^{a}$ Corresponding author: c/o Agripolis, viale dell'Università, 16 - 35020 Legnaro (PD), Italy; (39) 345-0853089; camachojorge@,costarricense.cr

b Carretera Panamericana y Periférico Sur s/n, Bo. María Auxiliadora, San Cristobal de Las Casas, Chiapas, Mexico, CP29290; (52)-967-6779000; hmorales@,ecosur.mx

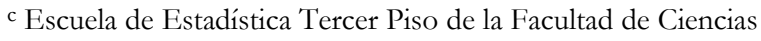
Económicas, UCR, San Pedro, San Jose, Costa Rica, CP2060; (506) 2267-6276; hipotesis delta@hotmail.com

d Carretera Panamericana y Periférico Sur s/n, Bo. María Auxiliadora, San Cristobal de Las Casas, Chiapas, Mexico, CP29290; (52)-967-6779000; asaldivar@ecosur.mx

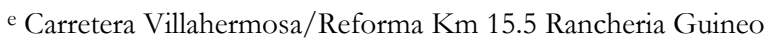
2a. Sección, Villahermosa, Tabasco, Mexico, CP86280;

(52)-(993)-3136110; ehuerta@ecosur.mx
}

constitutes a missed opportunity for community and economic development. Additionally, many innovations in household solid waste management are never adopted because they do not take into account existing local knowledge, preferences, behaviors, and management practices. In order to contribute to solving solid waste problems in small multicultural cities in Latin America, we conducted an interdisciplinary study that (1) documents current practices for managing organic waste and identifies citizens' willingness to compost household refuse; (2) analyzes whether composting municipal organic waste results in compost of adequate quality; and (3) identifies farmers' willingness to use this compost. We also identify innovative urban practices for organic waste management. Compost obtained during the study fulfilled minimum requirements for nutrients in compost according to international standards, despite the fact that no consistent composting 
methods were followed. The results indicate that household or neighborhood composting could contribute to solving urban organic waste problems as well as the lack of organic fertilizer available for agriculture in urban and peri-urban areas. While distributing compost could be a challenge, it also provides an opportunity to strengthen links between farmers and consumers.

\section{Keywords}

compost, domestic waste, environmental education, local knowledge, urban agriculture, vermiculture, Mexico

\section{Solid Waste Problems and Opportunities}

Poor management and disposal of domestic solid waste is one of the most common problems in cities worldwide (Del Carpio, Escamirosa, \& Castañeda, 2000; Xudong, Yong, \& Tsuyoshi, 2010). In most Latin American cities, solid waste is disposed in open-air dump sites, without consideration for environmental and public health risks (Del Carpio, et al., 2000; Escamiroza, Del Carpio, Castañeda, \& Quintal, 2001; Zarate, Slotnick, \& Ramos, 2008).

Governments of many cities see incinerators and municipal composting plants as possible solutions to garbage problems, and in some cases these have been implemented. Incinerators contribute to diminishing the volume of solid waste, and may be built with technologies to significantly reduce emissions. However, most existing incinerators generate toxic fumes, and the necessary equipment to eliminate the discharge is usually unaffordable for small cities in poorer nations (NOM-098-SEMARNAT, 2002; Öberg, Öhrstrom, \& Bergström, 2007). Furthermore, during the incineration process, potentially valuable organic matter is lost.

Some cities have successfully implemented municipal or private composting. For example, in Catalonia, Spain, $75 \%$ of the city's organic waste is processed in 25 composting plants (Barrios, Fernandez, Vasquez, \& Font, 2004), providing compost for urban and rural agriculture. However, since municipal composting processes garbage from a wide variety of unknown sources, further research is required regarding aspects of hygiene and toxicity in large-scale composting (Murillo, Cabrera, Lopez, \& Martin-Olmedo, 1995; Déportes, Benoit-Guyod, Zmirou, \& Bouvier, 1995; Farrell \& Jones, 2009).

The city of Loja, Ecuador (lat. 3059'35" S, long. $79^{\circ} 12^{\prime} 15^{\prime \prime} \mathrm{W}$ ), has also successfully implemented municipal composting. Loja has established a solidwaste treatment plant that includes recycling and worm composting using locally developed technology. Loja has a population of 150,000 and produces an average of 90 tons of solid waste daily J. Ramirez, personal communication, 20 June 2006). The composting plant processes $95 \%$ of this waste, $60 \%$ of which is organic. Most of the composted organic waste is used to fertilize public parks or is sold to local farmers (J. Ramirez, personal communication, 20 June 2006). In contrast, other communities that have initiated municipal composting have had difficulties such as residents not cooperating by separating their household waste. We believe, however, that some municipalities have significant potential given the right approach. In this paper we focus on one such case, San Cristobal de Las Casas (herein referred to as "San Cristobal"), in the southeastern Mexican

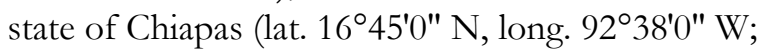
see figure 1 , next page). The aim of this study was to explore the feasibility of establishing a municipal composting program in San Cristobal, taking into account the current organic waste management practices of its residents.

San Cristobal, with a population of 180,000 , is similar in size to Loja. Approximately 170 tons of solid waste is produced daily in San Cristobal (Vasquez-Sanchez, Ramos, Mendez, Diaz, \& Valencia, 2004). The great majority of this waste is deposited in an open-air dumpsite, without consideration for the environment or the health of the local population. In 2005 , the city tried to initiate a waste-separation program in some neighborhoods. The program failed due to a lack of containers for separating materials, as well as logistical problems when the same vehicle collected both organic and nonorganic waste (A. Garcia, personal communication, 3 October 2005). The 


\section{Figure 1. Map of Mexico Indicating Location of San Cristobal de Las Casas}

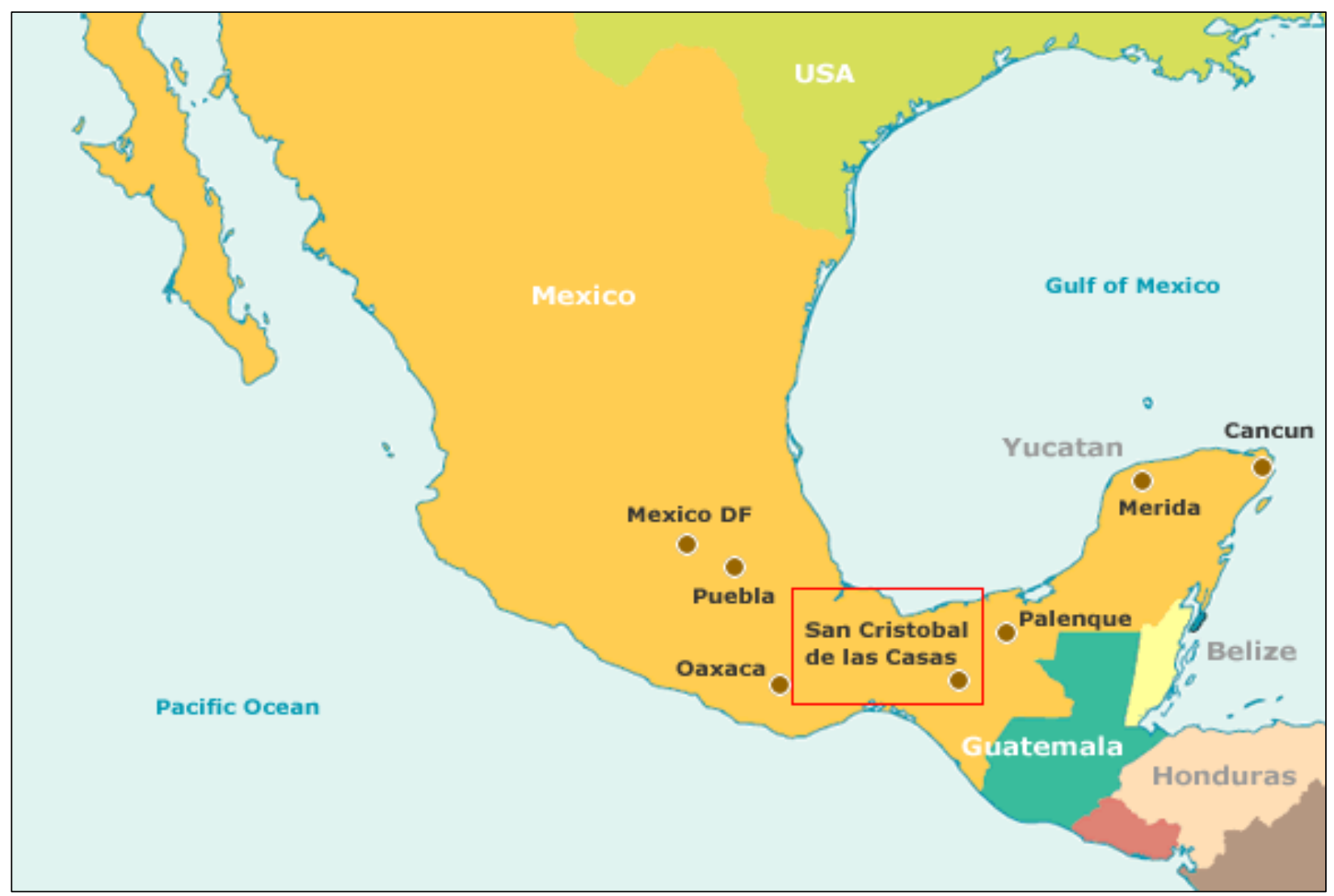

only study available regarding San Cristobal waste estimated that $62 \%$ of the city's solid waste was organic (Aguado, 1998). Based on our observations, this percentage has not changed significantly over the past decade. San Cristobal has great potential for producing compost for both domestic and municipal use. Some local government officials believe that municipal composting plants could be established. However, they report that at least in the short term they cannot afford to establish an integrated waste-management program. Such a program would include a composting facility as well as programs to motivate and teach citizens to separate their garbage (Vasquez-Sanchez, et al., 2004).

In the past, when municipal authorities have sought alternative waste-management solutions, they have not sought the opinions of local residents. Past alternatives involved techniques exclusively from other locations that were not only rejected, but also threatened to displace existing local techniques. These efforts disregarded the possibility that local techniques could be more efficient and sustainable, as they are adapted to local conditions. According to the logic of constructivist theory for solving community problems (Coll, 2002), one means of minimizing solid-waste problems is to identify existing local techniques and initiatives among citizens and promote them broadly across the population. Successful implementation of an integrated wastemanagement program requires marrying traditional organic waste-management practices and other aspects of daily community life with the public interests and motivations regarding new ideas and technology. That is, people are more likely to adopt new practices if they do not involve drastic changes in their lives. The premise of our study was that documenting local knowledge and practices is an important early step toward a successful wastemanagement plan that includes composting. 
Mayan farmers throughout the Mesoamerican highlands near San Cristobal still cultivate the land using traditional farming practices and are generally aware of the benefits of compost, such as higher yields and reduced pest damage. However, since the cold climate does not facilitate rapid production of biomass, farmers lack resources to produce a sufficient amount of organic compost for their crops (Morales, Perfecto, \& Ferguson, 2001). Making composted urban waste available to them could help solve this problem. However, in order to ensure that farmers adopt the use of compost produced with organic municipal waste, their opinions and concerns - for example, with respect to quality, availability, price, cost of transport, and health risks - must also be taken into account. Addressing these concerns regarding the use of compost could help develop strategies to safely use and even market this product.

In urban and peri-urban areas, solid-waste disposal problems could be greatly resolved by composting organic waste, which would also provide local farmers with organic fertilizer. This interdisciplinary project involving the biological and social sciences had the following objectives: first, to document San Cristobal residents' current organic waste-management practices, and to measure their willingness to separate organic waste and compost at home, and second, to study whether waste in San Cristobal is suitable for vermiculture (worm composting), as well as for conventional pile composting. Thus, we sought to determine the most efficient method in terms of cost, time, and management that would produce a high-quality product and be adapted to San Cristobal lifestyles. The final objective was to identify current fertilization practices of San Cristobal farmers as well as their level of willingness to use compost made from organic municipal waste. Although our study documents the case of San Cristobal, this approach could be implemented in similar projects in other cities around the world.

\section{Methods}

The current study explored three areas of research: (1) documenting current practices for managing organic waste and identifying citizens' willingness to compost household refuse; (2) determining whether municipal organic waste is adequate for composting; and (3) identifying farmers' willingness to use this compost. The methods we used are outlined below.

\section{Willingness of San Cristobal Residents To Separate Organic Waste, and Current Organic Waste-Management Practices}

Six citizen focus groups were organized in San Cristobal neighborhoods and schools, with an average of 10 participants in each group. The objective was to discuss the issue of solid-waste management, verify the vocabulary to be used for the broader survey, and motivate local citizens to participate in trials of neighborhood composting.

We used a random sampling technique to distribute the survey to 369 households located in 40 of the 115 city sectors. Households were selected according to a two-stage conglomerate sample (Scheaffer, Mendenhall, \& Ott, 1987). We aimed to ensure that confidence intervals for percentages obtained had an estimation error no greater than $10 \%$.

Survey questions were categorized according to topic. Each question had several categories of response. For each category, the number of people per city block who responded affirmatively to each category was counted, as well as the proportion of affirmative responses in each category. Estimation error was calculated using the formulas suggested for sampling by conglomerates (Scheaffer, et al., 1987).

\section{Suitability of San Cristobal Waste for Vermiculture and Conventional Pile Composting} Trial composting systems were developed in order to determine the suitability of San Cristobal waste for composting. Four community composting sites were established among the focus groups' participants and another in a local research center. These groups included people of different socioeconomic and educational levels. In each site, a workshop was held to explain how to separate waste and compost and to establish participants' responsibilities. This project was carried out over a sixmonth period. Two composting methods were 
tested at each of the five sites: worm composting (vermiculture), using Eisenia andrei and E. foetida; and conventional, or "pile," composting, in which wastes are piled one meter high and turned and watered once or twice per week until the organic matter decomposes. Food waste and yard debris collected at each site were divided between the two compost piles in order to guarantee that each pile had a similar composition of waste. Neighbors cooperated to collect organic waste daily and take it to a central compost pile (see appendix for details on type of waste used, temperature, $\mathrm{pH}$, and duration of the compost piles).

The two types of finished compost were compared for quality using a paired samples design. Nutritional content, pathogen levels, and heavy metal content of both types of compost were also analyzed. The Student's t-test for paired samples was used to determine whether the composting method significantly affected outcome. Confidence intervals were calculated for the average of each response variable in order to evaluate whether results obtained were within established limits. This analysis was carried out using the statistical package SPSS, version 12.0 (SPSS Inc. 2003). The two compost methods were also evaluated in terms of cost, space required, aeration, size of particles in each substratum, and participants' preferences.

\section{Farmers' Fertilization Practices and Willingness To} Use Compost Made From Organic Municipal Waste Finally, field interviews of a sample of farmers were conducted to determine their current fertilization methods, their willingness to use and buy compost made from organic municipal waste, under what conditions they would be willing to use it, and any reasons they might not be willing to do so. The survey included 43 farmers in three agricultural neighborhoods in the area surrounding San Cristobal whom we found working in their plots and who agreed to speak with us. Each question had several response categories. The number of farmers who responded affirmatively to each category was counted and the proportion of affirmative responses in each category was calculated. This survey identified farmers' general point of view regarding composting. While this limited sample does not allow us to generalize about all farmers in the San Cristobal region, survey results do offer some insight into their potential interest in using community organic waste.

\section{Results}

\section{Current Waste Management Practices and Residents' Willingness To Compost}

\section{Household separation and management of organic waste We found that $41.1 \%$ of respondent households already separate and compost organic waste in order to deal with their solid waste. This may be an overestimate, as some respondents who say they separate and compost may not do so consistently. This could be verified through future observation.}

Local organic waste-management practices include composting, feeding food scraps to pets and farm animals, saving waste for neighbors' animals, burying waste, and using organic waste in their gardens (figure 2). Food scraps fed to one's own or neighbors' animals are referred to in San Cristobal as hacbibual. With respect to burying organic waste, some respondents reported using a single pit, while others dig several small pits and fill them over time. Some inhabitants who use organic waste in the garden put their non-composted organic waste in a blender and use the resulting liquid to water their plants.

Compost methods currently used by San Cristobal residents are pile $(2.5 \%)$, pit $(1.7 \%)$, combination pit and layered $(1.2 \%)$, layered $(0.5 \%)$, worm composting $(0.3 \%)$, and other $(1.7 \%)$. In pit composting, organic waste is placed in a hole in the ground. When it is full, it is covered with earth, turned, and watered as necessary. Layered compost is made by layering organic waste, sawdust, limestone, and soil. These layers are covered and left to decompose for two to three months. The compost is then turned and used. Several other composting methods were identified in the category of "other actions":

(1) kitchen and garden waste is placed along with charcoal in a large plastic bag, and the contents are stirred once a month; (2) small areas in the garden are filled with organic waste, cow manure, ash, and 
leaf litter, and turned and watered when necessary; and (3) organic waste mixed with soil is deposited in a receptacle, which is then closed, allowing the contents to decompose.

Of those who separate their waste, $21.6 \%$ take it to the curbside for city garbage pick-up. The most common reason for separation is to minimize unpleasant odors and diseases at home. However, many people appear unmotivated to separate waste, as they see it collected and mixed together in the garbage truck. Thirty-seven percent of respondents say they do not separate organic and inorganic waste (figure 2).

Initially, $65 \%$ of those interviewed $(n=369)$ stated that they understood the concept of organic waste. However, when asked to distinguish organic from nonorganic waste products, only half responded correctly, $7 \%$ of responses were incorrect, and another $3.2 \%$ had confused the concept, believing organic to be nonorganic and vice versa.

Those who responded correctly $(n=209)$ were then asked to provide a definition of organic waste, and responses were grouped into several general categories. The majority of respondents generally defined organic waste as vegetable and fruit peels and leaves, while others defined it as materials that putrefy or decompose, materials that can be used to make compost, natural materials, or kitchen waste (figure 3).

\section{Residents' willingness to separate} organic waste and compost at home Ninety percent of respondents who
Figure 2. Current Organic Waste Management Practices of San Cristobal Inhabitants $(n=369)$

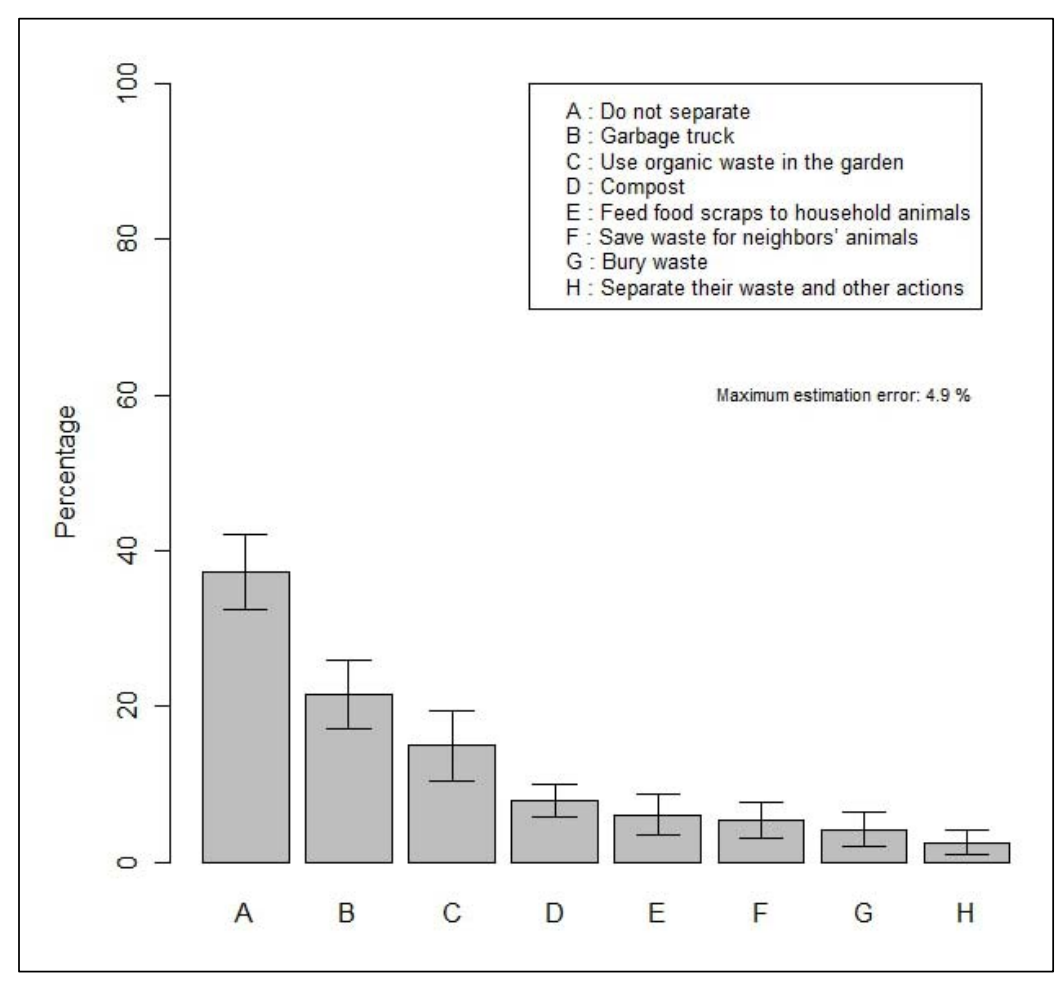

Figure 3. San Cristobal Respondents' Definitions of Organic Waste $(n=209)$

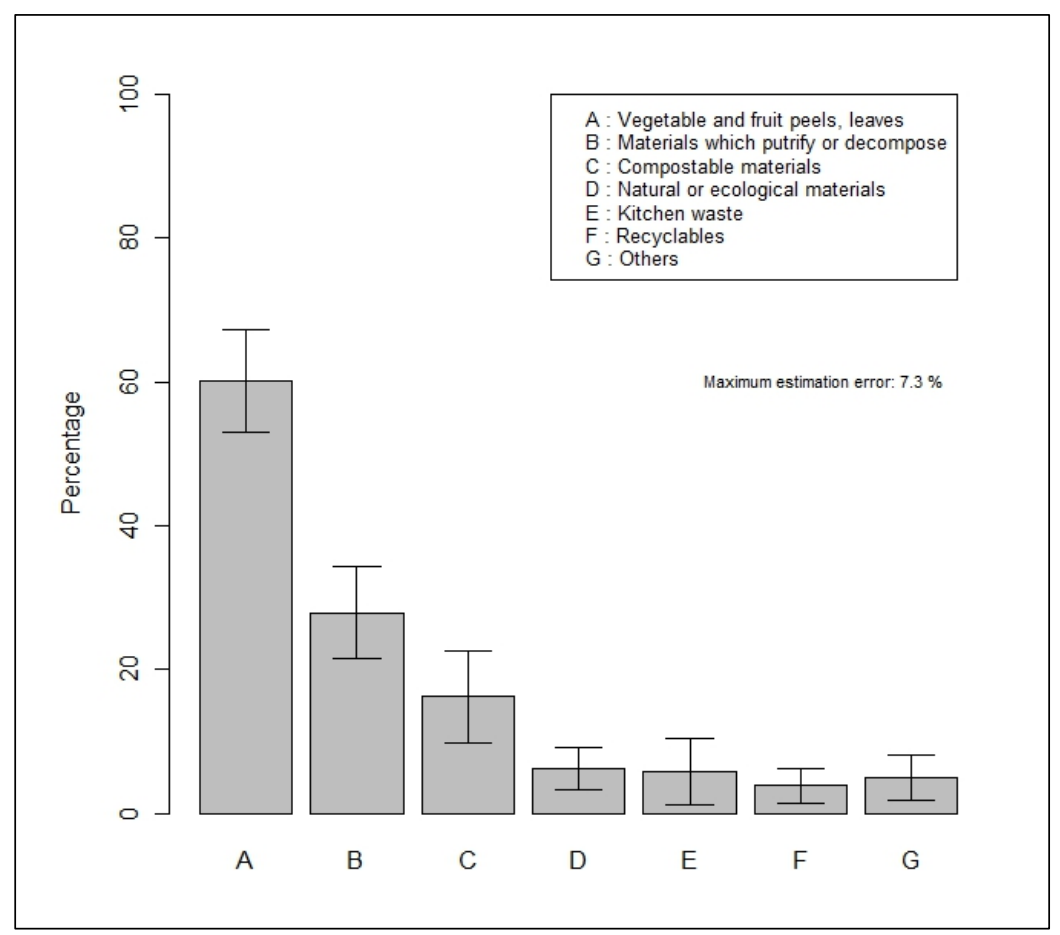


Figure 4. Reasons Why Respondents Willing To Separate Do Not Currently Do So $(n=137)$

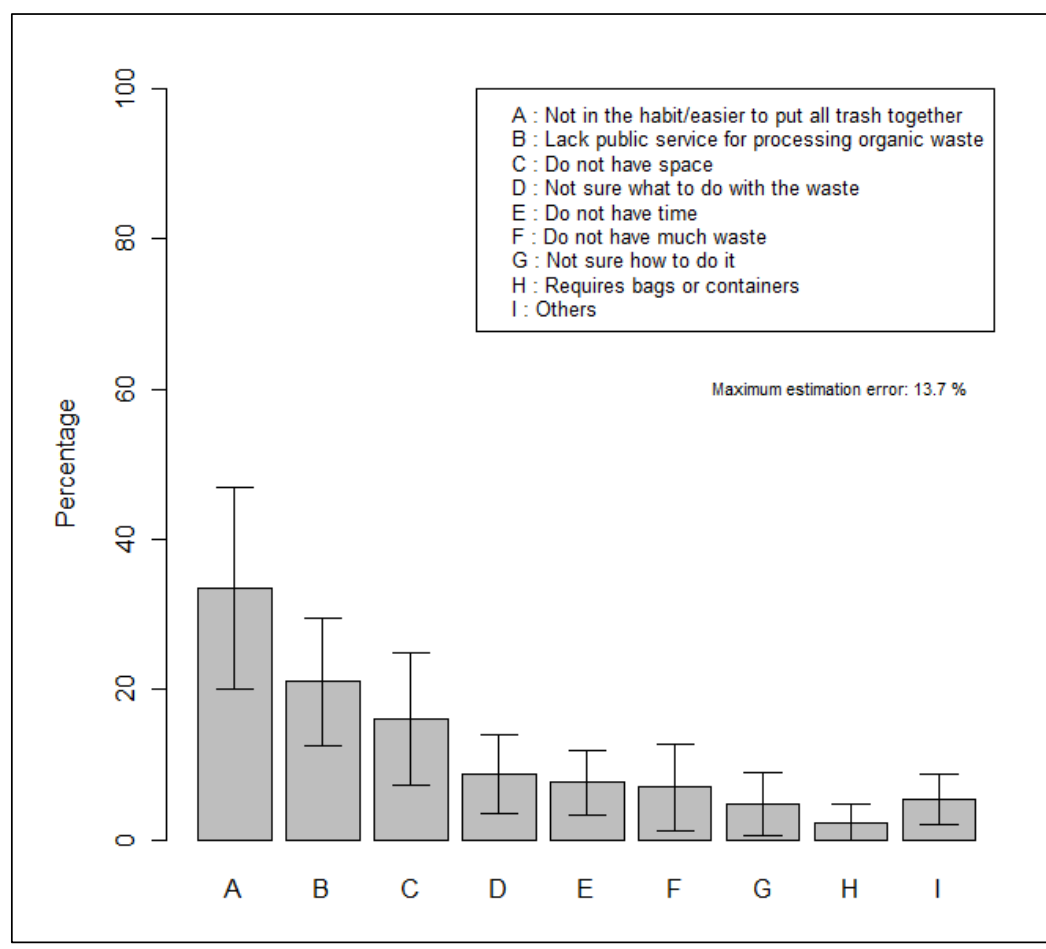

Figure 5. Actions To Be Taken with Separated Organic Waste Among Respondents Willing To Separate $(n=127)$

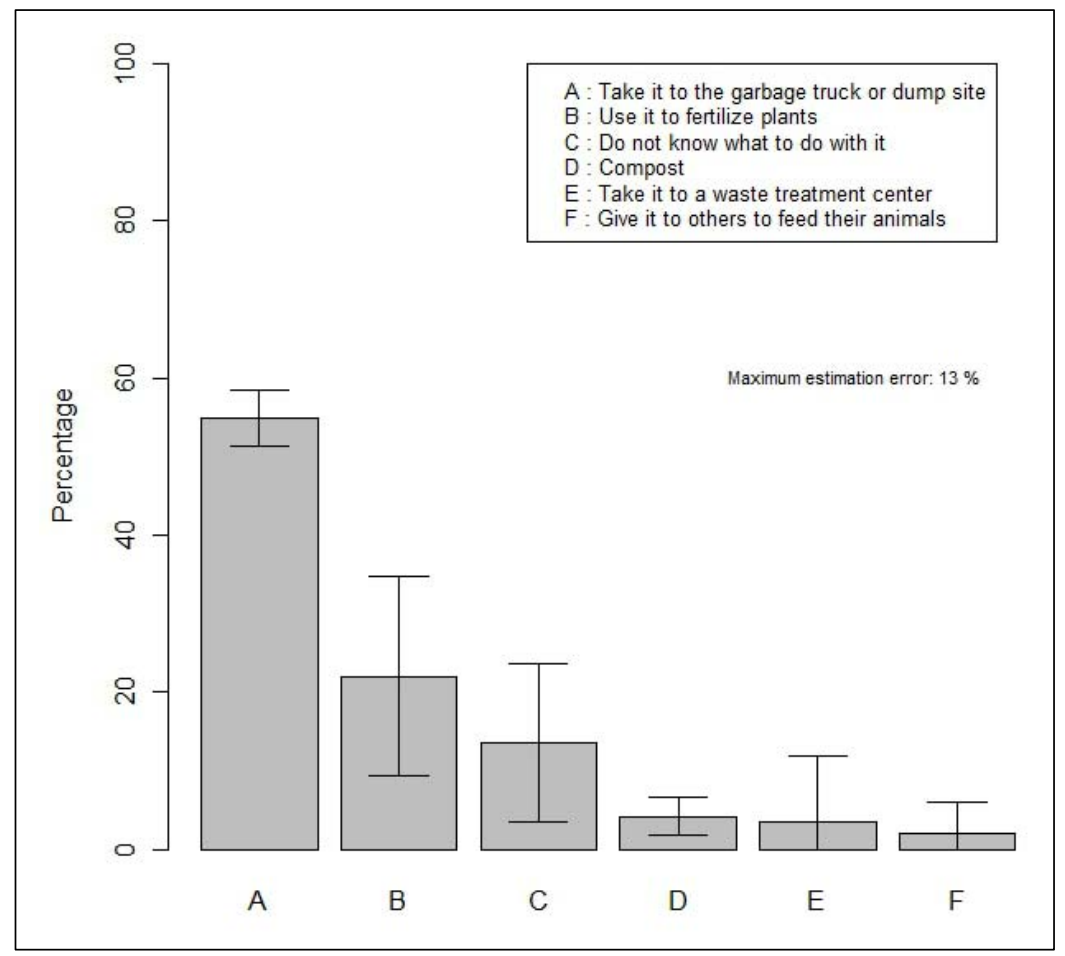

do not currently separate $(\mathrm{n}=137)$ said they would be willing to do so. This high level of willingness may suggest that people recognize the severity of the waste-management problem. Of those interviewed, $31.9 \%$ mentioned "garbage in the streets, on corners, and vacant lots" as one of the city's major problems.

Respondents who expressed a willingness to separate but who currently do not do so were asked why they do not separate.

Responses included: "Not in the habit/easier to put all trash together," "There is no processing or management available," "Do not have space," "Not sure what to do with the waste," "Do not have time," "Not sure how to do it," and "Requires bags or containers" (figure 4).

Respondents who said they would separate $(n=127)$ were asked what they would do with separated organic waste. The majority answered, "I would take it to the garbage truck or dump site," while others said "I would take it to a treatment center" or "I do not know what to do with it." Some respondents who do not separate their organic waste indicated that they knew they could benefit by doing so. Twenty-two percent of those said, "I could use it to fertilize my plants," referring to the technique of simply burying fresh waste beneath their plants. Fewer said they could compost $(4.2 \%)$, and some said, "I could give it to others to feed their animals" $(2.0 \%)$ (figure 5$)$.

Nearly $40 \%$ of all respondents $(\mathrm{n}=369)$ reported a willingness to compost their own organic mate- 
rials, although they do not currently do so. Respondents providing a reason $(n=115)$ gave the following reasons for not composting: "I have no idea that it is possible to compost organic waste," "I do not know how to do it," "I do not have space," and "I do not have time" (figure 6).

Those expressing unwillingness to compost their own organic waste $(n=201)$ were asked to identify their reasons. Some reasons relate to insecurities and fears. These include, "I have concerns about bad odors, flies, worms, and rats," "I feel it would be too much work," and "I do not see the point" (figure 7). More insecurities and fears were included in the category of "other": (1) "Composting is done only in rural areas and it harbors contaminants,"

(2) "Dogs destroy it," and

(3) "Children might upset it."

Finally, the survey asked if they would be willing to participate in community composting. Fortyseven percent of respondents said yes, $39.6 \%$ said no, and $13.0 \%$ did not know or did not respond.

Comparison of Composting Methods Among Different Groups in San Cristobal

\section{Costs and operability}

In San Cristobal, as perhaps in most communities, worm composting requires much greater initial investment than conventional pile composting. The cost of worm composting in our study was 960 Mexican pesos (approximately USD85) for 500 worms, wood, and labor to build the worm
Figure 6. Reasons Why Respondents Willing To Compost Do Not Currently Do So $(n=115)$

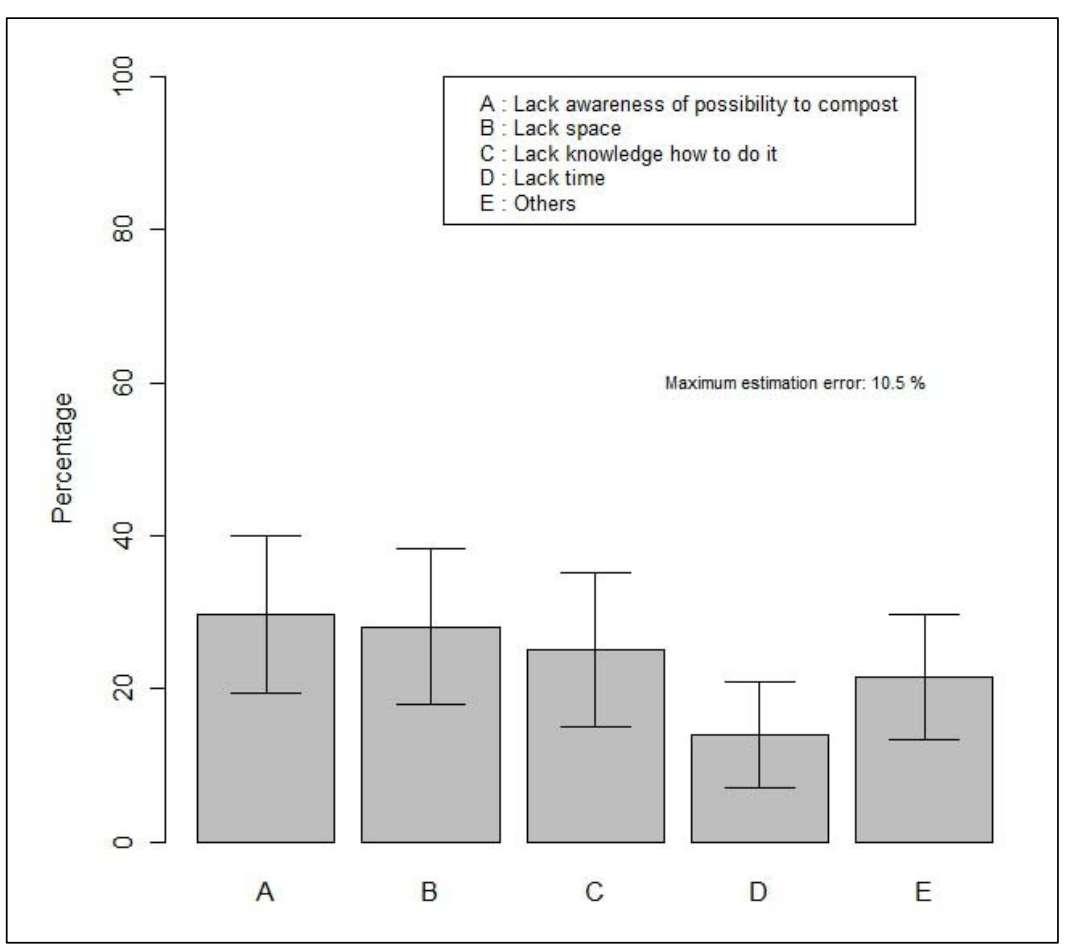

Figure 7. Reasons Some Respondents Are Not Willing To Compost $(n=201)$

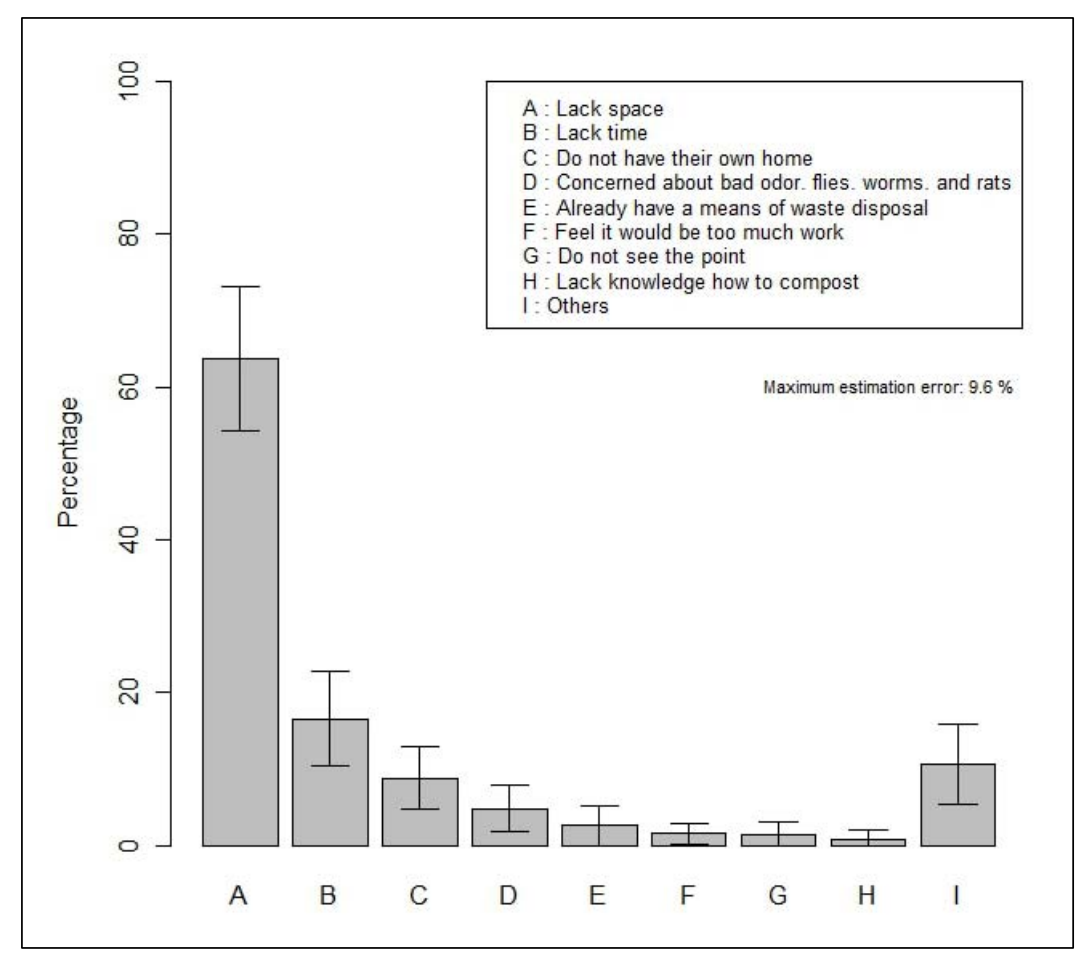


boxes. On the other hand, conventional compost piles require no special materials. It should be noted that worm compost requires special care; it cannot be exposed to direct sunlight, should be watered regularly, and must be protected from predators such as birds and ants.

Conventional composting, however, requires more work than worm composting. After a wormless "precomposting" stage of one month, worms are added but the compost is not turned, as this would stress the worms (Díaz, Savage, Eggerth, \& Golueke, 1993). A conventional compost pile must be turned once or twice per week (Romero, 2000) to ensure aeration, which facilitates waste degradation and prevents bad odors, elevates temperature, and diminishes pathogens (Díaz, et al., 1993). Having organic materials in small pieces in compost may accelerate the decomposition process. Small particles may favor microflora and microfauna activity and help the material decompose more rapidly (Martínez, 2000). In two of the neighborhood composting sites, particles were smaller and therefore easier to manipulate, and decomposition occurred rapidly in both pile and worm composts. On the other hand, compost at the institutional site contained many orange peels and whole vegetables, and thus was hard to turn and aerate, had bad odors, and decomposed more slowly. In all sites the compost pile never reached a height of one meter (3 feet), was not built in layers as recommended, and did not reach the desired internal temperatures. Nevertheless, as shown below in table 1, the resulting compost was acceptable in quality.

Many participants in the neighborhood trial composting sites were surprised at how easy composting was. They said they had never composted before because they thought it was very complicated. In additional, many inhabitants (52\% according to our survey) buy leaf litter gathered from surrounding forests for their gardens. Composting their waste instead can reduce the use of leaf litter that may cause environmental problems in the area.

\section{Chemical Composition of Conventional and Worm Composts}

\section{Nutrient content}

Table 1 (next page) compares results of nutrient content analysis for the conventional and wormbased compost trials at the five sites. Samples analyzed from both methods showed nutrient contents within limits established by the FAO for compost. In the analysis of macronutrients, total average nitrogen $(\mathrm{N})$ content was $1.6 \%$ for conventional compost and $1.7 \%$ for worm compost. These averages are just above the upper limit of $1.6 \%$ specified by the FAO (Dalzell, Riddlestone, Gray, \& Thurairajan, 1987). The difference between the two averages was not significant when applying the Student's t-test for paired samples $(\mathrm{p}=0.78)$.

Average potassium $(\mathrm{K})$ content was $0.9 \%$ for worm compost and $0.7 \%$ for conventional compost. Both were above levels specified by the FAO $(0.2 \%-0.6 \%)$. Significant differences existed in the Student's t-test for paired samples for the two methods $(p=0.06)$, with a level of significance of 0.10 . The $90 \%$ confidence interval indicates that worm composting produced from $0.035 \%$ to $0.364 \%$ more potassium than pile composting.

Averages for phosphorus $(\mathrm{P})$ were $0.3 \%$ for worm compost and $0.2 \%$ for conventional compost. These averages were within limits specified by the FAO for municipal compost $(0.1 \%-0.4 \%)$. Significant differences were found for phosphorus $(p=0.04)$, with a significance level of 0.05 . We found, with $95 \%$ confidence, that worm composting produced from $0.004 \%$ to $0.135 \%$ more phosphorus than pile compost.

With respect to micronutrients, no significant difference was found between the two methods for magnesium $(\mathrm{Mg})(\mathrm{p}=0.90)$. Average $\mathrm{Mg}$ concentration for worm compost was $630.2 \mathrm{mg} / \mathrm{kg}$, compared to $622.2 \mathrm{mg} / \mathrm{kg}$ for pile compost. According to the FAO based on studies in other areas, $\mathrm{Mg}$ content should be between 385 and $1600 \mathrm{mg} / \mathrm{kg}$. In our trials, $\mathrm{Mg}$ falls within these limits for both methods. 
The carbon/nitrogen relationship $(\mathrm{C} / \mathrm{N})$ in all five experimental sites showed an average of 11 for worm compost and 10 for pile compost. The Student's t-test for paired samples $(\mathrm{p}=0.21)$ shows that the average difference between the two methods was not significant. According to Tisdale and Nelson (1970), in soils high in organic materials, this relationship should be approximately 10 .

No significant difference was found $(\mathrm{p}=0.49)$ in average content of organic matter between worm composting (21.2\%) and conventional composting (22.7\%). The FAO (Dalzell, et al., 1987) indicates that organic matter in compost ranges from $25 \%$ to $80 \%$. Compost made with municipal waste is usually closer to the lower limit, while compost made with farm or garden waste tends to be closer to the higher limit. As the compost in this study was composed mostly of municipal waste, it is closer to the lower limit, although neither average reaches $25 \%$.
Heavy metal and pathogen content

Table 1 above also shows results of analysis for heavy metals. Average chromium (Cr) content was $156.6 \mathrm{mg} / \mathrm{kg}$ in worm compost and $189.9 \mathrm{mg} / \mathrm{kg}$ in pile compost. Lead $(\mathrm{Pb})$ showed an average content of $14.0 \mathrm{mg} / \mathrm{kg}$ in worm compost, and 34.0 $\mathrm{mg} / \mathrm{kg}$ in pile compost. In both cases, no significant differences were found $(\mathrm{p}=0.30$ for chromium, and $\mathrm{p}=0.14$ for lead). For lead, averages found in worm and conventional composts are lower than the established minimum $(<300 \mathrm{mg} / \mathrm{kg})$ for biosolids in compost. Chromium is also below the established minimum for biosolids $(<1200$ $\mathrm{mg} / \mathrm{kg}$ ) in both composting methods (ContrerasRamos, et al., 2005). With respect to human health, lower lead and chromium contents are safer.

The enteropathogens Salmonella tiphi and Escherichia coli were not detected in laboratory tests for either the worm or conventional composts in any of the five experimental sites. Absence of these pathogens

Table 1. Nutrients and Heavy Metals Found at Five Trial Sites Using Two Methods of Urban Organic Waste Composting in Chiapas, Mexico

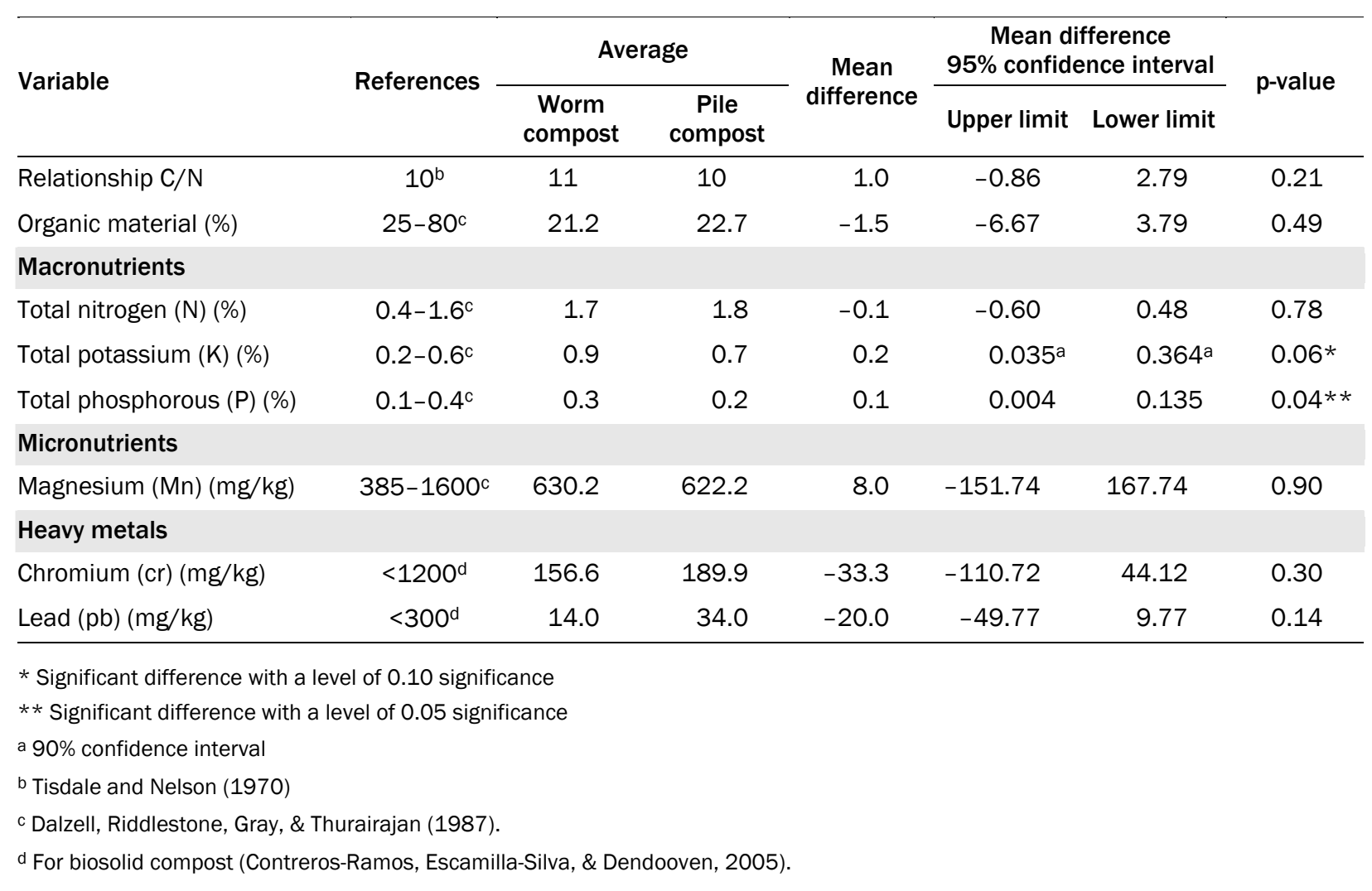


is very important, as these bacteria present serious risks to human health (Koneman, Allen, Janda, Schreckenberger, \& Winn, 1999).

\section{Current Farmer Practices and}

Willingness To Use Compost from

Organic Municipal W aste

Of the 43 farmers interviewed, $76.7 \%$ were men and $23 \%$ were women; $65.1 \%$ were over age 40 and $34.9 \%$ were under 40 . Of the interviewees, $88.4 \%$ reported using some kind of fertilizer, whether organic or artificial, to improve harvests. The interviews of San Cristobal-area farmers indicated that many use organic materials as fertilizer. Organic residues from corn crops are used as frequently as urea, a commonly used synthetic nitrogen fertilizer. Besides crop residues, other organic fertilizers they reported using are "chicken manure," "organic waste (ash, vegetable remainders, and leaves)," "cow or sheep manure," and "leaf litter." The synthetic fertilizers known commercially as " $18-46-00$ " (18\% nitrogen and $46 \%$ phosphorus) and "Triple 17" (17\% nitrogen,

Figure 8. Fertilization Used by San Cristobal Growers From Survey of Farmers in Areas Surrounding San Cristobal $(n=43)$

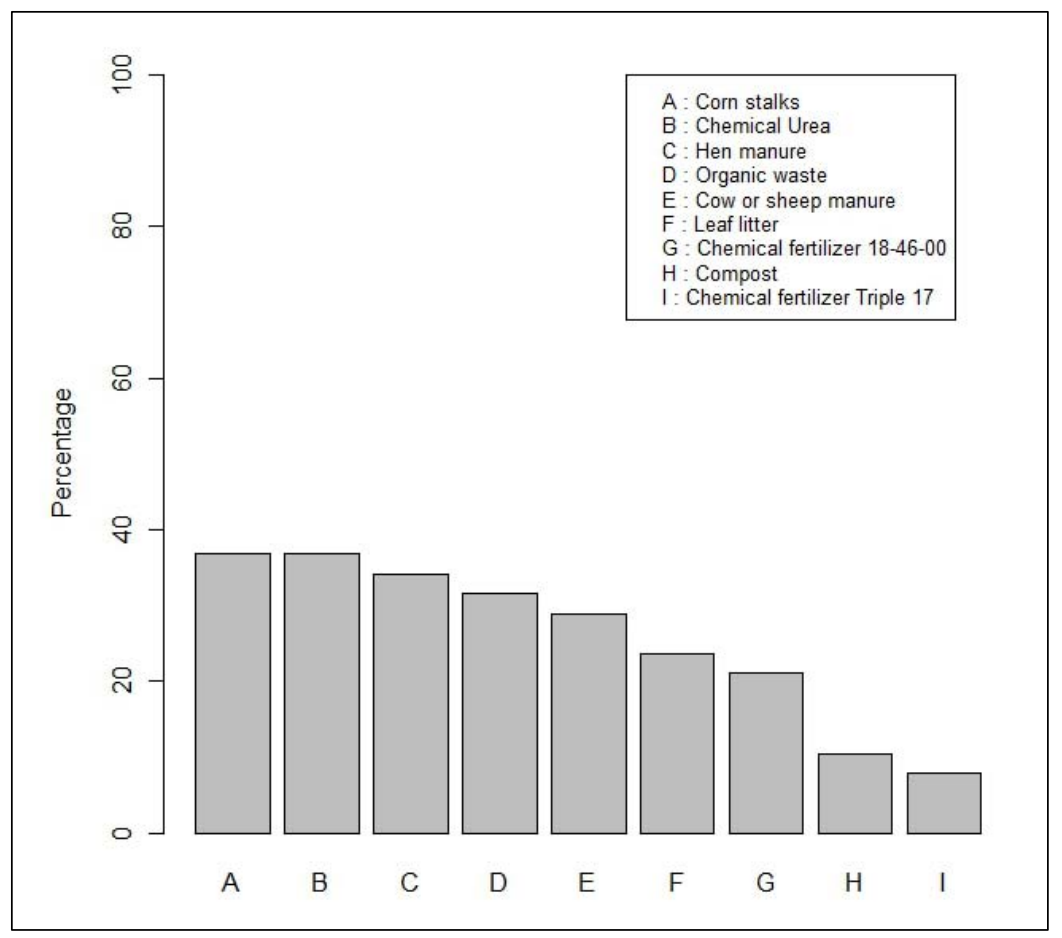

$17 \%$ phosphorus, and $17 \%$ potassium) are also used by San Cristobal farmers (figure 8).

Among the interviewees ( $\mathrm{n}=43), 74.4 \%$ of respondents said they would be willing to use compost made with organic city waste, $23.3 \%$ said they would not, and 2.3\% said did not know. For those who said no, reasons given were "it has a bad odor and could cause illness," "city garbage would contain microbes, plastic, or glass," "bugs would contaminate the vegetables," and "city garbage is filthy."

Of those farmers willing to use compost made with organic municipal waste, $96.9 \%$ would be willing to purchase it. However, $29.2 \%$ of all farmers surveyed said they must be allowed to try it and test its quality before committing to a purchase and that it must be cheaper than chemical fertilizer. Twelve percent indicated they would use municipal compost if it did not contain inorganic waste. Respondents' support for using municipal compost is supported by the following opinions: two farmers mentioned that it was common for farmers to collect soil for their plants at municipal waste-disposal sites. One farmer interviewed said, "I've always thought that we in the countryside were lacking resources found in city waste." This indicates the potential for introducing new ideas and practices regarding fertilizer to area farmers.

\section{Discussion}

Organic waste management appears to be an important traditional practice for part of the population of San Cristobal. However, it remains to be determined whether the practical methods developed from people's creativity and the necessity of managing organic waste result in good quality compost and if they could be adapted successfully at a larger scale. These methods have helped local people to dispose of their organic waste in the face of 
inadequate municipal waste-disposal programs. Since a considerable proportion of the population does not separate organic and inorganic waste, a great deal of potential compost is not available. For this fairly large portion of the population, an education campaign to explain why and how to separate organic waste should be implemented if the city hopes to establish a successful, long-lasting organic waste management program. In such a campaign, it is important to use terms with which people are familiar. The definitions provided by respondents could be useful in disseminating concepts more widely.

In our first objective for this study, we explored residents' attitudes, perceptions, and knowledge about organic waste management. Many people are not motivated to separate waste, as they see it collected and mixed with other waste in the garbage truck. Others expressed a willingness to separate but currently do not separate for different reasons, such as because they believe they lack the ability to process the waste and manage the compost. At the same time, the high level of willingness to separate organic from inorganic waste may suggest that people recognize the severity of the waste management problem. This is supported by the fact that they mention garbage in the streets, corners, and vacant lots as one of the major problems in the city. A municipal system in which organic and inorganic waste is processed separately might motivate residents to separate.

In general, people who were willing to separate said they preferred to not have to process their own organic waste. This suggests that local residents see a municipal organic waste collection and management system as an attractive option for managing their garbage problem. On the other hand, the high percentage of the population responding positively to community composting indicates potential to initiate neighborhood-level waste separation and composting in certain areas. A more representative sample of each neighborhood would be necessary before initiating programs.

Survey responses indicate support for the need to develop an integrated waste-management system that includes education and training regarding the importance, benefits, and methods of separating waste. According to constructivist education theory (Saldivar, 2001), projects must make use of people's current resources and incorporate local knowledge. Municipal authorities and other parties interested in urban waste problems should promote practices already in use to a wider audience of city inhabitants who might be interested, but are currently uninformed of these practices.

New policies may be intimidating, but when they fully consider residents' concerns and wishes, these policies are more likely to be adapted (COSUDE, 1991). A municipal organic waste collection and management system should introduce educational programs that take into consideration residents' problems, fears, and insecurities with respect to odors and rats and with managing worms.

Many inhabitants buy leaf litter gathered from surrounding forests for their gardens. This suggests a need for organic fertilizer in the city. While this study did not compare the effects of compost and leaf litter on plant growth, there is a potential local market for compost made with municipal waste. Furthermore, substituting leaf litter with municipal compost may help preserve forests, since germination of forest seedlings may be adversely affected by the loss of leaf litter.

The second objective of our project was to study whether urban waste in San Cristobal is suitable for vermiculture (worm composting), as well as for conventional pile composting. Although worm composting has a higher cost, once established its costs are minimal. Other cost-cutting possibilities are establishing a municipal worm bank or neighborhood worm sharing, which would operate outside conventional market prices; starting with fewer worms and using recycled material for boxes; or worm composting directly in the soil (Biologist M. Anzueto, personal communication, 4 October 2004).

The fact that worm composting requires special care could represent disadvantages to this method (Díaz, et al., 1993). However, some of these diffi- 
culties may easily be overcome. For example, we found it takes only about 10 minutes weekly to water the compost. In addition, some participants had fears regarding worms. Those with the strongest fear and repulsion did not want to touch or even see them. This could pose a strong limitation that must be addressed when promoting neighborhood worm composting.

In the neighborhood composting test sites, the resulting compost was acceptable even though the compost piles never reached the recommended height and temperature. This suggests that it is not essential to follow experts `strict rules for proportions of fresh and dry material, size, layers, etc., and that the composting process is fairly flexible and may be simplified to fit urban conditions. Other compost methods already in use in the city, such as burying waste in a hole or liquefying waste to apply to gardens, should be tested to see whether they could be implemented on a larger scale.

Nutrient levels in both compost types complied with requirements of the FAO. Furthermore, the heavy-metal content did not represent a risk for human health, and enteropathogens were absent. Thus, municipal waste in San Cristobal appears to be acceptable for producing compost. Furthermore, according to Diaz (1993), one of the advantages of worm composting is its high mineral content. For example, worm compost has high phosphorus content and could improve the phosphorus-poor soils of the region (Reich \& Oleksyn, 2004).

Our final objective was to identify the willingness of San Cristobal-area farmers to use compost made from organic municipal waste, as well as their current fertilization practices. The survey of area farmers indicated that many use organic material as fertilizer. Widespread use of organic fertilizer represents an opportunity for introducing organic compost made with the city waste.

Some farmers' fears related to the quality and sanitation of composted organic municipal waste could reflect real problems and should be addressed if a system for composting city garbage is to be established. Aspects that must be taken into account when defining strategies for producing and marketing these products include quality control, product price, and cost of transport. These concerns are also commonly expressed by farmers elsewhere (for example, see Mohammad, Hodges, \& Kiker, 2004).

\section{Conclusions}

We conclude that San Cristobal's organic waste is adequate for producing viable compost. In terms of quality, the organic waste produced in these trials contained the nutrients necessary to produce healthy crops. The cost of producing pile compost is much lower than that of worm compost. However, if adequate programs are implemented for reproduction and distribution of worms, such as establishing worms directly in the soil or using recycled material to make worm boxes, costs may be reduced. In terms of operability and management, worm composting requires less work than conventional composting. Both options could be offered to city residents who wish to compost. However, traditional local methods should be tested on a broader level. Many people do not compost because they perceive composting to be a complicated process with strict rules. However, our research shows that composting is not necessarily complicated. Scientists and community organizers should emphasize the wide variety of possible methods and encourage citizens to experiment with new options and to adapt composting techniques to their own conditions. Finally, people's concerns, fears, knowledge, and lifestyles must be taken into account when developing methodologies for promoting composting.

One option for motivating urban residents to compost is to find ways to market the finished compost to the municipality, to neighbors, or to nearby farmers. To achieve this, municipal composting projects must work to increase the acceptance of the product and find stable markets (Gillis, 1992). In the case of San Cristobal, 74.4\% of farmers interviewed indicated a willingness to buy and use compost made with organic municipal waste. Other possible consumers of organic compost made from municipal waste are urban resi- 
dents themselves. Approximately half of San Cristobal residents traditionally buy forest leaf litter for their gardens and potted plants, and thus represent potential compost buyers. Concerns regarding quality and price, as well as fears that the compost might contaminate crops, must be taken into account when formulating marketing strategies. It is essential to guarantee adequate separation of waste, ensuring that compost does not contain inorganic materials, and also to price the compost competitively with chemical fertilizers. It is also necessary to conduct periodic analyses to ensure that the compost's nutrient content is adequate for obtaining a good harvest.

Organic waste-management practices and vocabulary already used by San Cristobal residents should be considered when taking further steps to implement an organic waste separation and management program. Those who separate waste but do not compost could be informed of composting alternatives already practiced by their neighbors (placing the material in bags or receptacles, or burying it in small holes). They could also be informed of benefits and methods of fertilizing their gardens with organic waste. We recommend helping residents develop systems compatible with their available space and time.

Knowledge and practices of San Cristobal residents should be incorporated in the management of this city's waste. The fact that local organic waste is adequate for producing viable compost, and that farmers wish to purchase high-quality organic compost, suggest that the municipal government together with interested local nongovernmental organizations could create a successful alternative waste-management system based on separating and composting organic waste. Furthermore, composting could represent an important opportunity to start microenterprises or small business whose staff pick up the organic waste, compost it, and sell the resulting compost to local farmers or to residents for use in their gardens.

In many urban areas of Latin America it is common to find livestock, mainly chickens, in resi- dents' yards. Residents might be encouraged to offer their neighbors selected kitchen scraps to feed their animals. With the ongoing food crisis such practices could become even more critical, as urban residents are increasingly motivated to grow their own food (Lynch, Binns, \& Olofin, 2001).

Implementing an integrated system of organic waste management offers municipalities alternatives for resolving urban garbage problems. However, urban residents do not need to wait for the city to implement a municipal compost plant. As lack of space is an issue for many urban residents, small composting sites located around the neighborhood - in schools, churches, parks, or abandoned lots, for example — could be an economical and efficient way to dispose of organic waste while producing a useful product.

Another challenge to successful community composting projects is distributing the compost to farmers. Farmers' markets and community supported agriculture (CSAs) or similar programs could help build this bridge. As has occurred in Asia for centuries (McNeill \& Winiwarter, 2004), partial exchange of vegetables for compost could contribute to a strong relationship between farmers and consumers. In many parts of the world, urban residents have traditionally planted fruit trees and aromatic herbs in their home gardens. Due to recent worldwide economic and food crises, interest in locally grown food has increased, and many urban residents now plant vegetables as well. Thus, the demand for organic compost is increasing worldwide, and this provides a great opportunity to reduce garbage, find new sources of nutrients, and above all, strengthen links between farmers and consumers.

\section{Acknowledgements}

Thanks to El Colegio de La Frontera Sur (ECOSUR) for financing this study and to San Cristobal citizens for their participation in this project, to Anne Greenberg for her editorial services, and to the anonymous JAFSCD reviewers for their comments to the manuscript. 


\section{Appendix}

Temperature, Duration, and Composition of Two Methods of Composting Urban Organic Waste in Chiapas, Mexico

\begin{tabular}{|c|c|c|c|c|c|c|c|}
\hline \multirow{2}{*}{ Place } & \multirow{2}{*}{$\begin{array}{l}\text { Compost } \\
\text { method }\end{array}$} & \multicolumn{2}{|c|}{ Temperature $\left({ }^{\circ} \mathrm{C}\right)$} & \multicolumn{2}{|c|}{$\mathrm{pH}$} & \multirow{2}{*}{ Duration } & \multirow{2}{*}{ Type of waste } \\
\hline & & Mean & Std. dev. & Mean & Std. dev. & & \\
\hline \multirow{2}{*}{ Ecosur } & Worm compost & 20.6 & 2.9 & 6.7 & 0.3 & 5 months & $\begin{array}{l}\text { 70\% fresh materials: orange, } \\
\text { pineapple, lime, banana, lettuce, } \\
\text { avocado, carrot, potato, beet, }\end{array}$ \\
\hline & Pile compost & 21.9 & 3.6 & 6.8 & 0.3 & 5 months & $\begin{array}{l}\text { - } 30 \% \text { dry materials: paper, leaves, } \\
\text { pine needles }\end{array}$ \\
\hline \multirow{2}{*}{ Pequeño Sol } & Worm compost & 25.0 & 5.2 & 6.7 & 0.3 & 4 months & $\begin{array}{l}\text { 80\% fresh materials: orange, } \\
\text { pineapple, mango, watermelon, } \\
\text { avocado, potato, eggshell, corn }\end{array}$ \\
\hline & Pile compost & 26.1 & 3.2 & 6.5 & 0.3 & 4 months & $\begin{array}{l}\text { husk, corn kernels, etc. } \\
\text { - } 20 \% \text { dry materials: paper, grass }\end{array}$ \\
\hline \multirow{2}{*}{ Preparatoria } & Worm compost & 23.5 & 3.9 & 6.3 & 0.7 & 4 months & $\begin{array}{l}80 \% \text { fresh materials: orange, lime, } \\
\text { banana, mango, watermelon, } \\
\text { papaya, avocado, carrot, beet, }\end{array}$ \\
\hline & Pile compost & 24.1 & 2.3 & 6.3 & 0.6 & 4 months & $\begin{array}{l}20 \% \text { dry material: paper, grass, } \\
\text { pine needles }\end{array}$ \\
\hline \multirow{2}{*}{ Tlaxcala } & Worm compost & 22.1 & 4.8 & 6.6 & 0.3 & 5 months & $\begin{array}{l}\text { 75\% fresh materials: orange, lime, } \\
\text { banana, cauliflower, pumpkin shell, } \\
\text { potato, carrot, corn husk, corn }\end{array}$ \\
\hline & Pile compost & 24.4 & 4.8 & 6.5 & 0.3 & 5 months & $\begin{array}{l}\text { kernels, etc. } \\
\text { - } 25 \% \text { dry materials: paper, leaves }\end{array}$ \\
\hline \multirow{2}{*}{ Santa Lucía } & Worm compost & 22.9 & 4.1 & 6.6 & 0.3 & 5 months & $\begin{array}{l}\text { 85\% fresh materials: orange, } \\
\text { pineapple, banana, mango, } \\
\text { watermelon, papaya, cactus fruit, } \\
\text { carrot, potato, squash, radish, }\end{array}$ \\
\hline & Pile compost & 24.5 & 2.0 & 6.6 & 0.3 & 5 months & $\begin{array}{l}20 \% \text { dry materials: paper, grass, } \\
\text { leaves }\end{array}$ \\
\hline
\end{tabular}




\section{References}

Aguado, J. (1998). Residuos sólidos domésticos en SCLC, Chiapas: Generalización per cápita y caracterización. (Unpublished master's thesis). Chiapas, Mexico: El Colegio de la Frontera Sur.

Barrios, S., Fernandez, R., Vasquez, F., \& Font, X. (2004). Composting activity in Catalonia. Biocycle, 42(2), 64-66.

Coll, C. (2002). Desarrollo psicológico y educación. Constructivismo y educación: La concepción constructivista de la enseñanza y el aprendizaje (pp. 157-186). Madrid, Spain: Alianza Editorial.

Contreras-Ramos, S. M., Escamilla-Silva, E. M., \& Dendooven, L. (2005). Vermicomposting of biosolids with cow manure and oat straw. Biology and Fertility of Soils, 41(3), 190-198. doi:10.1007/s00374-004-0821-8

COSUDE. (1991). Viabilidad de proyectos de desarrollo. Lineamientos básicos y transformación práctica. Berna, Switzerland: Dirección de Cooperación Suiza al Desarrollo y Ayuda Humanitaria.

Dalzell, H. W., Riddlestone, A. J., Gray, K. R., \& Thurairajan, K. (1987). Soil management: Compost production and use in tropical and subtropical environments. FAO Soils Bulletin no. 56. Rome: Food and Agriculture Organization.

Del Carpio, C. U., Escamirosa, L. F. \& Castañeda, G. (2000). Problemas urbanos de Tuxtla Gutiérrez: Chiapas, México: Universidad de Ciencias y Artes de Chiapas.

Déportes, I., Benoit-Guyod, J. L., Zmirou, D. E., \& Bouvier, M. C. (1995). Microbial disinfection capacity of municipal solid waste (MSW) composting. Journal of Applied Microbiology, 85, 238246. doi:10.1046/j.1365-2672.1998.00484.x

Díaz, L. F., Savage, G. M., Eggerth, L. L., \& Golueke, C. G. (1993). Composting and recycling municipal solid waste. Boca Raton, Florida: Lewis Publishers.

Escamirosa, L. F., Del Carpio, C. U., Castañeda, G., \& Quintal, C.A. (2001). Manejo de los residuos Sólidos domiciliarios en la ciudad de Tuxtla Gutiérrez Chiapas. Mexico City: Plaza y Valdés, S.A.

Farrell, M., \& Jones, D. L. (2009). Critical evaluation of municipal solid waste composting and potential compost markets. Bioresource Technology, 100(19), 4301-4310. doi:10.1016/j.biortech.2009.04.029

Gillis, A. M. (1992). Shrinking the trash heap. Bioscience, 42, 90-93. doi:10.2307/1311649

Koneman, E.W., D. Allen, S., Janda, W.M., Schreckenberger, P.C., \& Winn W.C. (1999). Diagnóstico microbiológico. Madrid, Spain: Editorial Médica Panamericana.

Lynch, K, Binns, T., \& Olofin, E. (2001). Urban agriculture under threat: The land security question in Kano, Nigeria. Cities, 18(3), 159-171. doi:10.1016/S0264-2751(01)00008-7
Martínez, C. C. (2000). Lombricultura, alternativa en la agricultura sustentable. En C. C. Martínez y F. L. Ramírez (Eds.), Lombricultura y agricultura sustentable (pp. 135-153). México, DF, MX.

McNeill, J. R., \& Winiwarter, V. (2004). Breaking the sod: Humankind, history, and soil. Science 304(5677), 1627-1629. doi:10.1126/science.1099893

Mohammad, R., Hodges, A. W., \& Kiker, C. F. (2004). Compost users' attitudes toward compost applications in Florida. Compost Science \& Utilization, 12(1), 55-60.

Morales, H., Perfecto, I., \& Ferguson, B. (2001). Traditional fertilization and its effect on corn insect populations in the Guatemala highlands. Agriculture, Ecosystems and Environment, 84, 145-155. doi:10.1016/S0167-8809(00)00200-0

Murillo, J. M., Cabrera, F., Lopez, R. \& Martin-Olmedo, P. (1995). Test low-quality urban compost for agriculture: germination and seedling performance of plants. Agriculture, Ecosystems \& Environment, 54(1), 127-135. doi:10.1016/0167-8809(94)00576-Z

NOM-098-SEMARNAT. (2002). Norma Oficial Mexicana con especificaciones sobre incineración de residuos, especificaciones de operación y límites de emisión de contaminantes. Mexico: Diario Oficial 2004.

Öberg, T., Öhrstrom, T., \& Bergström, J. (2007). Metal catalyzed formation of chlorinated aromatic compounds: A study of the correlation pattern in incinerator fly ash. Chemosphere 67(9), S185-S190. doi:10.1016/i.chemosphere.2006.05.098

Reich, P. B., \& Oleksyn J. (2004). Global patterns of plant leaf $\mathrm{N}$ and $\mathrm{P}$ in relation to temperature and latitude. Proceedings of the National Academy of Sciences, 101(30), 11001-11006. doi: $10.1073 /$ pnas.0403588101

Romero, M.R. (2000). Vermicomposteo y Agricultura Sustentable. Agricultura orgánica. Elaboración y aplicación de abonos orgánicos. Mexico City.

Saldivar, A. (2001). Diseño de estrategias socioeducativas para el desarrollo: Acercando la educación al desarrollo en Chiapas. Cultura y Educación, 13(1), pp. 21-36. doi: $10.1174 / 113564001316901748$

Scheaffer, R. L., Mendenhall, W., \& Ott, L. (1987). Elementos de muestreo. Mexico City: Grupo Editorial Iberoamérica, S.A. de C.V.

Tisdale, S. L., \& Nelson, W. L. (1970). Soil fertility and fertilizers. Hong Kong: Kwok Hing Printing Press.

Vasquez-Sanchez, M. A., Ramos, M. M., Mendez, E., Diaz, D., \& Valencia, E. (2004). Estudio de la Planta de Manejo de residuos sólidos en San Cristóbal de Las Casas, Chiapas. Chiapas, Mexico: Ayuntamiento municipal de SCLC, Secretaria de 
Journal of Agriculture, Food Systems, and Community Development ISSN: 2152-0801 online

www.AgDevJournal.com

Desarrollo Social, Programa Hábitat, El Colegio de la Frontera Sur.

Xudong, C., Yong, G., \& Tsuyoshi, F. (2010). An overview of municipal solid waste management in China. Waste Management, 30(4), 716-724.

doi:10.1016/j.wasman.2009.10.011
Zarate, M. A., Slotnick, J., and Ramos, M. (2008). Capacity building in rural Guatemala by implementing a solid waste management program. Waste Management, 28(12), 2542-2551. doi:10.1016/j.wasman.2007.10.016 
Journal of Agriculture, Food Systems, and Community Development ISSN: 2152-0801 online www.AgDevJournal.com 